\title{
Profil Protein Trypanosoma evansi dari Daerah Geografis Berbeda di Indonesia Tahun 2012-2014 dengan Sodium Dodecil Sulphate Polyacrylamide Gel Electrophoresis
}

\author{
(TRYPANOSOMA EVANSI PROTEIN PROFILE OF DIFFERENT GEOGRAPHICAL \\ AREAS ORIGIN IN INDONESIA FROM 2012-2014 BY USING SODIUM DODECIL \\ SULPHATE POLYACRYLAMIDE GEL ELECTROPHORESIS)
}

Fitrine Ekawasti ${ }^{1 *}$, Ichwan Yuniarto ${ }^{2}$, Sulinawati ${ }^{3}$, Didik Tulus Subekti ${ }^{1}$

${ }^{1}$ Balai Besar Penelitian Veteriner, JL. RE Maratadinata 30, Bogor, Jawa Barat, Indonesia16114

*Email: fitrineekawasti@gmail.com ${ }^{2}$ Balai Veteriner Banjar Baru, Jl. Ambulung 24, Banjarbaru, Kalimantan Selatan, Indonesia 70712 ${ }^{3}$ Balai Veteriner Lampung, JL. Untung Suropati 2, Bandar Lampung, Lampung, Indonesia 35142

\begin{abstract}
ABSTRAK
Wabah Surra pada tahun 2012 telah menyebabkan lebih dari 1.700 hewan telah mati di Provinsi Nusa Tenggara Timur (NTT) Indonesia. Kasus berlanjut secara sporadis sampai hari ini di berbagai daerah, terutama Kalimantan, Banten dan juga daerah lainnya. Beberapa laporan menyatakan adanya perbedaan profil protein di antara beberapa isolat T. evansi. Tujuan penelitian ini adalah untuk mengetahui profil protein masing-masing isolat $T$. evansi di Indonesia sehingga dapat menjadi dasar untuk pengembangan kit diagnosis penyakit Surra pada ternak. Sebelas isolat yang berasal dari provinsi Nusa Tenggara Timur, Kalimantan Selatan dan Kalimantan Tengah, Banten, Lampung dan Bengkulu telah diisolasi dan dipurifikasi menggunakan DEAE. Trypanosoma kemudian di frezee-thawing berulang untuk mendapatkan protein terlarut. Selanjutnya protein terlarut diperlakukan dengan pemanasan dan tanpa pemanasan kemudian masing-masing dielektroforesis pada SDS PAGE dengan pewarnaan Coomassie Blue. Profil protein semua isolat dibandingkan keragaman biologinya. Hasil penelitian ini menunjukkan bahwa sebelas isolat $T$. evansi dari Indonesia memiliki profil protein sangat beragam, maka untuk keperluan pengembangan kit diagnostik dapat digunakan whole lysate cell (WCL) sebagai stok antigen dalam proses uji serologis
\end{abstract}

Kata-kata kunci: surra; Trypanosoma evansi; profil protein; SDS PAGE

\begin{abstract}
Surra outbreak in 2012 has led to more than 1,700 animals have died in the province of East Nusa Tenggara (NTT) Indonesia. Surra case sporadically continues throughout the year in various areas, especially Kalimantan, Banten as well as other areas. Some reports reveal differences in protein profiles among multiple isolates of T. evansi. Therefore the purpose of this research were to find out the protein profile of each isolate $T$. evansi in Indonesia and the possible biological differences among them. Eleven isolates originating from the province of East Nusa Tenggara, South Kalimantan and Central Kalimantan, Banten, Lampung and Bengkulu has been isolated and purified Using DEAE. Trypanosoma isolate were frezeethawing repeatedly to obtain soluble protein. Furthermore, soluble protein is treated with heating or without heating and then each was run on SDS PAGE with Coomassie Blue staining. The protein profiles of all isolates were compared each other. The results showed that eleven isolates of T. evansi in Indonesia has a very diverse protein profile. Then for the purposes of development of diagnostic kit can be used whole lysate cell (WCL) as stock antigen in serological test process.
\end{abstract}

Keywords: surra; Trypanosoma evansi; protein profile; SDS PAGE 


\section{PENDAHULUAN}

Surra adalah penyakit yang disebabkan oleh Trypanosoma evansi (T. evansi) yang disebarkan melalui vektor mekanik lalat penghisap darah (haematophagus flies). Umumnya fatal pada kuda dan kerbau, sedangkan pada sapi umumnya bersifat kronis dan menyebabkan kerugian ekonomi akibat kekurusan dan kelemahan. Parasit ini tersebar luas di kawasan Asia Tenggara, Afrika, dan Amerika (Davison et al., 2000; Abdel-Rady, 2008; Ravindran et al., 2008). Wabah Surra telah terjadi pada tahun 2010 hingga tahun 2012 untuk di seluruh Pulau Sumba, dan menyebabkan kematian sebanyak 1.159 kuda, 600 kerbau dan sapi (DGLAH, 2012). Saat ini, kejadian Surra masih berjangkit secara sporadis di beberapa provinsi seperti di Kalimantan, Lampung, dan Banten.

Pengendalian Surra belum optimal dilakukan karena adanya berbagai laporan yang membuktikan adanya keragaman $T$. evansi khususnya yang berkaitan dengan kepekaan beberapa galur terhadap beberapa trypanosidal (Yuniarto, 2016). Beberapa T. evansi telah diisolasi dari beberapa hewan yang menderita Surra di berbagai provinsi sejak tahun 20122014. Isolat T. evansi yang berasal dari pulau Sumba, khususnya di Sumba Timur telah berhasil diteliti dan dilaporkan memiliki subpopulasi yang berbeda terkait dengan pola parasitemia, patogenesis, dan virulensi (Subekti et al., 2013). Hasil ini konsisten dengan laporan dari De-Menezes et al. (2004) yang telah melaporkan adanya perbedaan pola virulensi dan parasitemia pada populasi $T$. evansi di Brasil. Subekti et al. (2015) juga melaporkan adanya perbedaan sensitivitas beberapa isolat T. evansi dari Indonesia terhadap beberapa jenis trypanosidal. Bukti-bukti tersebut mengindikasikan kemungkinan adanya keanekaragaman hayati pada populasi T. evansi yang berkaitan dengan variasi biologi.

Identifikasi profil protein dapat dilakukan dengan berbagai macam teknik, di antaranya adalah berdasarkan profil protein hasil elektroforesis pada gel poliakrilamid dengan sodium dodecyl sulphate polyacrylamide gel electrophoresis (SDS PAGE). Delamare et al. (2002) telah menggunakan teknik SDS PAGE untuk membandingkan profil protein dari Aeromonas sp pada tingkat spesies. Demikian pula halnya dengan Berber dan Berber (2006) yang membedakan beberapa isolat Bacillus $s p$ berdasarkan keragaman atau profil proteinnya pada tingkat spesies. Berber dan Ekin (2008) juga telah menggunakan SDS PAGE untuk membedakan galur atau subtipe beberapa isolat Candida albicans. Selanjutnya Tahmourespour et al. (2013) telah berhasil membedakan galur Streptococcus mutans dari pasien yang bebas karies gigi dengan galur yang berasal dari penderita karies gigi yang peka serta membedakannya dengan $S$. mutans dari ATCC 35668.

Uche et al. (1992) telah melakukan penelitian untuk membandingkan profil protein dari tiga isolat T. evansi yaitu isolat Indonesia, Mesir, dan Yaman. Hasil penelitian tersebut menunjukkan bahwa isolat Indonesia memiliki sedikit perbedaan dengan isolat Mesir tetapi keduanya memiliki perbedaan yang besar dibandingkan isolat dari Yaman. Singh et al. (1995) juga telah melaporkan adanya keragaman profil protein pada membran sel dari tujuh isolat T. evansi dari India bagian utara. Namun sebaliknya, penelitian yang telah dilakukan oleh Laha et al. (2008) tidak menemukan adanya perbedaan profil protein antara tiga isolat T. evansi yang berasal dari kuda, kerbau, dan sapi dari India Timur. Demikian pula Sivajothi et al. (2015) yang membandingkan profil protein dari empat isolat $T$. evansi yang diisolasi dari anjing di negara bagian Andhra Pradesh, India juga tidak berhasil menemukan adanya perbedaan.

Studi lain yang serupa telah dilaporkan oleh Nten et al. (2010) yang membandingkan profil protein dari T. brucei galur Beyamina dan STIB 215 juga tidak berhasil membedakan profil protein kedua isolat tersebut. Namun, Mejía et al. (2004) menginformasikan adanya profil protein yang sedikit berbeda dari T. cruzi galur Tulahuen dibanding galur SA dan klon Dm28c dari kultur axenik. Adapun Navaro et al. (2003) melaporkan adanya perbedaan profil protein dari $T$. cruzi yang berbeda stadium yaitu trypomatigot ekstraseluler dan metsiklik ekstraselular. Beberapa peneliti seperti Velasquez et al., (2014), Queiroz et al. (2001), Laha dan Sasmal (2008), dan Aquino et al. (2010) juga telah melakukan elekroforesis protein T. evansi, namun umumnya tidak membandingkan profil protein antar isolat tetapi lebih terfokus pada imunobloting. Berdasarkan latar belakang tersebut, adanya isolat T. evansi yang diperoleh dari berbagai daerah berbeda di Indonesia pada kisaran waktu 2012-2014 menimbulkan pemikiran untuk mempelajari 
adanya kemungkinan keragaman biologi atau perbedaan profil protein di antara isolat $T$. evansi dari beberapa daerah di Indonesia mengingat adanya bukti perbedaan biologi dari beberapa isolat tersebut yang terkait dengan kepekaan terhadap obat, pola parasitemia dan patogenesisnya sebagaimana telah dilaporkan Subekti et al. (2013). Oleh karena itu penelitian ini dilakukan untuk mengetahui profil protein masing-masing isolat $T$. evansi di Indonesia sehingga dapat menjadi dasar dalam pengembangan kit diagnostik Surra.

\section{METODE PENELITIAN}

\section{Asal Isolat T. evansi}

Isolat $T$. evansi yang digunakan dalam penelitian ini diisolasi dari hewan yang menderita Surra dari Kabupaten Sumba Timur, Provinsi Nusa Tenggara Timur, Kabupaten Serang, Provinsi Banten, Kabupaten Hulu Sungai Utara (HSU), Provinsi Kalimantan Selatan, Kabupaten Kotawaringin Timur, Provinsi Kalimantan Tengah, Kabupaten Bengkulu Selatan, Provinsi Bengkulu, dan
Kabupaten Pesawaran, Provinsi Lampung (Tabel 1.).

\section{Pemurnian T. evansi}

Darah yang mengandung T. evansi dikoleksi dan T. evansi selanjutnya dimurnikan dari darah mengikuti metode seperti yang dijelaskan OIE (2012). Secara singkat, trypanosoma dimurnikan dengan teknik kromatografi pertukaran anion (anion exchange chromatography) menggunakan DEAE 52 (Whatman, USA) yang telah disuspensikan di dalam PBS-G 1\% pH 8. Sekitar $8 \mathrm{~mL}$ suspensi DEAE dimasukkan ke kolom Poly-Prep ${ }^{\circledR}$ Chromatography (BioRad, Perancis) dan dibiarkan memadat. Setiap mililiter darah dituangkan secara hati-hati ke permukaan DEAE dan selalu dijaga agar tetap lembap menggunakan PBS-G 1\%. Suspensi murni trypanosoma dikumpulkan dalam tabung dan kemudian disentrifugasi pada kecepatan 3361 $\times \mathrm{g}, 4^{\circ} \mathrm{C}$ selama 15 menit menggunakan Allegra $^{\circledR}$ $X-15 R$ Centrifuge (Beckman Coulter). Supernatan dibuang dan endapan diresuspensi dengan PBS $\mathrm{pH} 7$ yang mengandung aprotinin 0,11 TIU/mL (setara 140,4 KIU/mL),

Tabel 1. Asal usul isolat T. evansi yang digunakan dalam penelitian ini

\begin{tabular}{|c|c|c|c|c|}
\hline Kode Isolat & Inang & Tahun Isolasi & $\begin{array}{c}\text { Daerah Asal Isolat } \\
\text { (kabupaten/propinsi) }\end{array}$ & Koordinat Geografi \\
\hline $\mathrm{S} 13$ & Kerbau & 2014 & Serang, Banten & $\begin{array}{c}7^{\circ} 36^{\prime} 52.3051^{\prime \prime} \mathrm{S} \\
110^{\circ} 42^{\prime} 44.0874^{\prime \prime} \mathrm{E}\end{array}$ \\
\hline $\mathrm{S} 18$ & Kerbau & 2014 & Serang, Banten & $\begin{array}{c}7^{\circ} 36^{\prime} 52.3051^{\prime \prime} \mathrm{S} \\
110^{\circ} 42^{\prime} 44.0874^{\prime \prime} \mathrm{E}\end{array}$ \\
\hline A13 & Kerbau & 2013 & $\begin{array}{l}\text { Hulu Sungai Utara, } \\
\text { Kalimantan Selatan }\end{array}$ & $\begin{array}{c}2^{\circ} 252033 \mathrm{~S} \\
115^{\circ} 142573 \mathrm{E}\end{array}$ \\
\hline A14 & Kerbau & 2014 & $\begin{array}{l}\text { Hulu Sungai Utara, } \\
\text { Kalimantan Selatan }\end{array}$ & $\begin{array}{c}2^{\circ} 252033 \mathrm{~S} \\
115^{\circ} 142573 \mathrm{E}\end{array}$ \\
\hline SPT & Kerbau & 2014 & $\begin{array}{c}\text { Kotawaringin Timur, } \\
\text { Kalimantan Tengah }\end{array}$ & $\begin{array}{c}2^{\circ} 312533 \mathrm{~S} \\
112^{\circ} 562583 \mathrm{E}\end{array}$ \\
\hline BGKU & Sapi & 2014 & $\begin{array}{c}\text { Bengkulu Selatan, } \\
\text { Bengkulu }\end{array}$ & $\begin{array}{c}4^{\circ} 27^{\prime} 27.89^{\prime \prime} \mathrm{S} \\
102^{\circ} 54^{\prime} 25.52^{\prime \prime} \mathrm{E}\end{array}$ \\
\hline PLS & Kerbau & 2014 & $\begin{array}{c}\text { Pesawaran, } \\
\text { Lampung }\end{array}$ & $\begin{array}{c}5^{\circ} 29^{\prime} 35.6820^{\prime \prime} \mathrm{S} \\
105^{\circ} 4^{\prime} 44.8464^{\prime \prime} \mathrm{E}\end{array}$ \\
\hline N370 & Kerbau & 2012 & $\begin{array}{c}\text { Sumba Timur, } \\
\text { Nusa Tenggara Timur }\end{array}$ & $\begin{array}{c}9^{\circ} 392243 \mathrm{~S} \\
120^{\circ} 152503 \mathrm{E}\end{array}$ \\
\hline N371 & Kerbau & 2012 & $\begin{array}{c}\text { Sumba Timur, } \\
\text { Nusa Tenggara Timur }\end{array}$ & $\begin{array}{c}9^{\circ} 392243 \mathrm{~S} \\
120^{\circ} 152503 \mathrm{E}\end{array}$ \\
\hline N372 & Kerbau & 2012 & $\begin{array}{c}\text { Sumba Timur, } \\
\text { Nusa Tenggara Timur }\end{array}$ & $\begin{array}{c}9^{\circ} 392243 \mathrm{~S} \\
120^{\circ} 152503 \mathrm{E}\end{array}$ \\
\hline N375 & Kerbau & 2012 & $\begin{array}{c}\text { Sumba Timur, } \\
\text { Nusa Tenggara Timur }\end{array}$ & $\begin{array}{c}9^{\circ} 392243 \mathrm{~S} \\
120^{\circ} 152503 \mathrm{E}\end{array}$ \\
\hline
\end{tabular}


selanjutnya disebut PBS-Aprotinin. Suspensi kemudian disentrifugasi lagi pada kecepatan $3361 \mathrm{x} \mathrm{g}, 4^{\circ} \mathrm{C}$ selama 15 menit. Langkah serupa diulang sampai 2 atau 3 kali. Terakhir, endapan kembali disuspensi dengan PBS-Aprotinin dan disimpan dalam freezer minus $20^{\circ} \mathrm{C}$ sampai pemurnian protein dilakukan.

\section{Pemurnian dan Kuantifikasi Protein}

Suspensi trypanosoma murni yang telah dihasilkan pada tahap sebelumnya dikeluarkan dari freezer dan dicairkan pada suhu kamar $\left(27^{\circ} \mathrm{C}\right)$. Pemurnian protein dari suspensi trypanosoma dilakukan dengan freeze-thawing secara berulang, sekitar 3-4 kali berturut-turut menggunakan nitrogen cair. Selanjutnya suspensi disentrifugasi pada kecepatan $3361 \mathrm{x}$ g selama 15 menit. Supernatan dipisahkan dari endapan, selanjutnya supernatan disebut sebagai Trypanosome Soluble Antigen (TSA). Konsentrasi protein TSA diukur menggunakan BioRad Protein Assay (BioRad, Perancis).

Konsentrasi total protein dari TSA ditetapkan dengan metode Bradford menggunakan BioRad Protein Assay (BioRad, Perancis). Secara ringkas, sebuah kurva standar dibuat menggunakan Bovine Serum Albumin (Sigma, USA), masing-masing pada konsentrasi 0,$00 ; 0,50 ; 0,75 ; 1,00 ; 1,25 ; 1,50 \mathrm{mg} / \mathrm{mL}$. Selanjutnya, masing-masing $10 \mathrm{uL}$ TSA dan protein standar dilarutkan dalam $190 \mathrm{uL}$ larutan Bradford. Setelah dihomogenisasi, 80 $\mathrm{uL}$ dari setiap standar protein dan protein sampel (TSA) dimasukkan ke lempeng mikro (flat bottomed 96well microplate, Nunc Denmark) dan dibaca pada Multiskan EX Colorimeter Reader (Thermo Scientific, Finlandia) pada $600 \mathrm{~nm}$. Nilai absorbansi kemudian dikonversi menjadi kadar protein dengan menggunakan analisis ProQuant ${ }^{\circ}$ Estimation of Protein Concentration.

\section{Elektroforesis Gel Poliakrilamida}

Protein trypanosoma (TSA) dari masingmasing isolat dielektroforesis pada SDS PAGE untuk membandingkan profil protein setiap isolat T. evansi. Sekitar $10 \mu \mathrm{g}$ TSA dari masingmasing isolat dicampur dengan buffer sampel (BioRad). Selanjutnya, sebagian dari TSA masing-masing isolat dipanaskan pada suhu $65^{\circ} \mathrm{C}$ selama lima menit dan sebagian lainnya tanpa pemanasan (Ekawasti et al., 2015). Setiap sampel dimasukkan kedalam lajur dari gel (TGX ${ }^{\text {тм }}$ pre cast gel $12 \%$, BioRad, Prancis) pada konsentrasi $10 \mu \mathrm{g} /$ lajur bersama dengan marka protein (RPN 800, Amersham Pharmacia). Elektroforesis dilakukan dengan menggunakan Mini Protean (BioRad) pada 150 volt sekitar 4550 menit. Hasil elektroforesis kemudian diwarnai menggunakan Coomassie Brilliant Blue. Penentuan pita protein dan densitometri dilakukan dengan menggunakan PhyElp 1.4 (Pavel dan Vasile, 2012).

\section{Analisis Data}

Hasil profil protein dilihat berdasarkan pola pita protein yang diekspresikan pada gel elektroforesis.

\section{HASIL DAN PEMBAHASAN}

\section{Profil Protein Isolat T. evansi dari Indonesia}

Profil protein pada hasil elektroforesis mempertimbangkan tiga faktor. Pertama adalah bobot molekul (MW) yang direpresentasikan dengan adanya migrasi vertikal masing-masing pita protein sesuai bobot molekulnya pada gel. Kedua, densitas warna yang dimanifestasikan sebagai ketebalan pita protein. Ketebalan pita protein tersebut menunjukkan konsentrasi protein tersebut secara proporsional terhadap total protein yang dianalisis dalam elektroforesis. Ketiga yaitu pola pita protein yang diperlihatkan dengan distribusi pita yang bermigrasi secara vertikal pada gel.

Setiap protein memiliki bobot molekul yang berbeda-beda. Oleh sebab itu, pita protein yang secara vertikal bermigrasi pada posisi yang berbeda dengan lainnya menunjukkan adanya perbedaan jenis protein. Giardina et al. (2003) melaporkan bahwa pita protein dari Trypanosome Soluble Antigen (TSA) berkisar antara 14,8-97,0 kDa sementara Laha et al. (2008) melaporkan pada kisaran antara 13-95 kDa. Pada penelitian ini, pita protein T. evansi dari berbagai daerah di Indonesia berkisar 17,2$184,4 \mathrm{kDa}$. Hasil ini memperlihatkan adanya perbedaan profil protein dibanding penelitian Laha et al. (2008) dan Giardina et al. (2003). Perbedaan tersebut diduga berkaitan dengan metode purifikasi maupun perbedaan isolat yang digunakan.

Pita protein yang tebal pada hasil penelitian ini secara acak terdistribusi dengan bobot molekul $35 \mathrm{kDa}$ sampai $100 \mathrm{kDa}$ tergantung 
pada isolat T. evansi, sedangkan penelitian yang dilaporkan oleh Laha dan Sasmal (2008) menemukan di sekitar $50 \mathrm{kDa}$ dan $60 \mathrm{kDa}$.

Berdasarkan ukuran pita dapat diketahui bahwa isolat N372 dan N370 maupun isolat BGKU dan PLS memiliki profil yang serupa, meskipun pada isolat BGKU terdapat beberapa pita yang tervisualisasi lebih samar dibanding isolat PLS (Gambar 1.A). Hal menarik ditemukan pada isolat A13 dan A14 yang diperoleh dari kerbau di desa yang sama tetapi mereka memiliki profil protein berbeda. Isolat A13 diperoleh pada tahun 2013 dan isolat A14 diperoleh pada tahun 2014. Perbedaan profil ini tidak dapat diartikan bahwa telah terjadi peristiwa mutasi pada populasi $T$. evansi di daerah itu, karena tidak adanya bukti perubahan dari isolat asal (yaitu A13) menjadi isolat baru (yaitu A14). Perbedaan profil protein dari isolat tersebut lebih cenderung mengarah pada keragaman populasi T. evansi di Kabupaten Hulu Sungai Utara, Provinsi Kalimantan Selatan.

Kecenderungan adanya keragaman populasi T. evansi juga dibuktikan pada isolat dari dua provinsi, yaitu NTT dan Banten. Empat isolat T. evansi dari NTT yaitu N370, N371, N372 dan N375 berasal dari desa yang sama di Sumba Timur dan juga diisolasi pada waktu yang bersamaan yaitu tahun 2012. Namun, berdasarkan hasil elektroforesis SDS PAGE dapat dilihat bahwa isolat N372 memiliki profil protein yang mirip dengan isolat N370 (Gambar 1). Sebaliknya, N372 dan N370 memiliki profil protein yang sangat berbeda dengan N371 dan N375 (Gambar 1). Bukti yang sama juga ditemukan pada T. evansi isolat $\mathrm{S} 13$ dan S18. Kedua isolat tersebut berasal dari

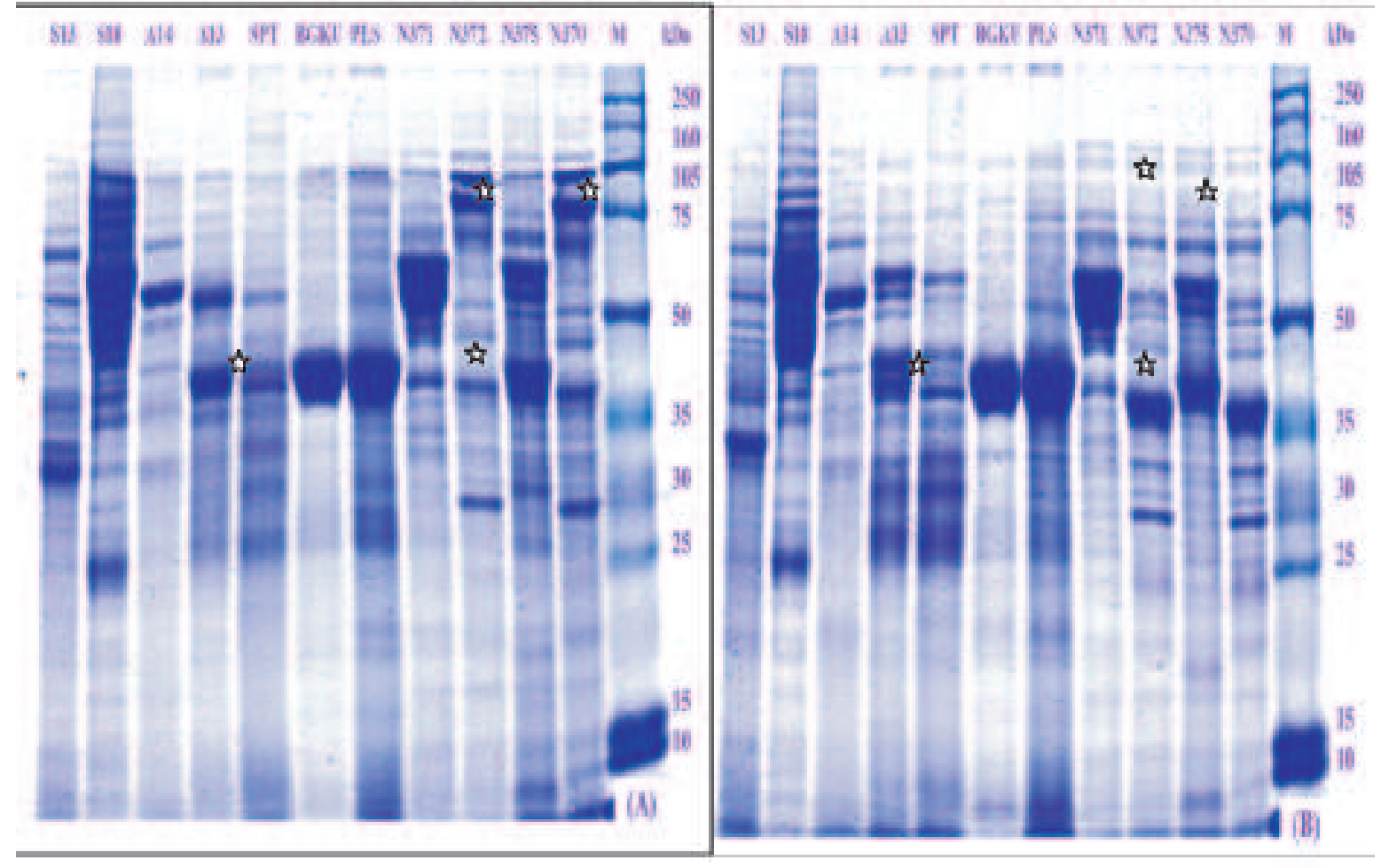

Gambar 1. Profil protein 11 isolat Trypanosoma evansi dari Indonesia pada gel poliakrilamid 12\% yang diwarnai dengan Coomassie Brilliant Blue. (A). Tanpa pemanasan (B) Dengan pemanasan $65^{\circ} \mathrm{C}$ selama 5 menit.

S13 dan S18: isolat T. evansi dari Kabupaten Serang, Propinsi Banten, A13 dan 14-: isolat T. evansi dari Kabupaten Hulu Sungai Utara, Propinsi Kalimantan Selatan, SPT: isolat T. evansi dari Kabupaten KotawaringinTimur, Propinsi Kalimantan Tengah, BGKU: isolat T. evansi dari Kabupaten Bengkulu Selatan, Propinsi Bengkulu, PLS: isolat T. evansi dari Kabupaten Pesawaran, Propinsi Lampung, N370, N371, N372 dan N375: isolat T. evansi dari Kabupaten Sumba Timur, Propinsi Nusa Tenggara Timur. 
daerah yang sama dan diisolasi pada waktu yang sama yaitu tahun 2014, tetapi memiliki profil protein yang juga sangat berbeda.

\section{Efek Pemanasan pada Profil Protein}

Protein memiliki struktur kuartener, tersier, sekunder, dan primer. Pada elektroforesis, struktur primer diperlukan untuk terjadinya migrasi protein pada gel poliakrilamid. Pemanasan diperlukan untuk mendenaturasi protein sehingga menjadi struktur primer, tetapi jika pemanasan pada suhu yang terlalu tinggi dalam waktu lama akan mengakibatkan denaturasi secara total sehingga terjadi kerusakan protein yang menyebabkan protein tidak dapat tervisualisasi pada gel poliakrilamid. Selain itu dengan pemanasan dapat diketahui sifat daya tahan protein terhadap suhu tertentu (Ekawasti et al., 2015).

Perubahan profil pita protein dari isolat T. evansi berdasarkan hasil SDS PAGE pada gel poliakrilamid $12 \%$ baik melalui proses pemanasan maupun tanpa pemanasan disajikan pada Tabel 2.

Hal demikian terbukti pada pemanasan protein TSA dari beberapa isolat T. evansi pada suhu $65^{\circ} \mathrm{C}$ selama 5 menit yang mengakibatkan perubahan profil protein pada SDS PAGE. Perubahan profil protein yang paling ekstrim terjadi pada protein TSA dari isolat N372 dan N370 (Gambar 1). Isolat lain yang juga mengalami perubahan profil protein adalah isolat A13. Pada isolat N370 dan N372, setelah pemanasan teramati adanya beberapa pita protein yang menghilang ataupun baru muncul dengan bobot molekul lebih kecil dari sebelumnya. Protein dengan bobot molekul sekitar 180 kDa dan 140 kDa (Gambar 2 dan Tabel 2) menjadi hilang setelah pemanasan. Sebaliknya protein dengan bobot molekul 70-80 kDa dan 95-100 kDa mengalami perubahan ketebalan pita proteinnya. Adapun pita protein dengan bobot molekul 32 dan $35 \mathrm{kDa}$ mengalami penambahan ketebalan pita protein (Tabel 2).
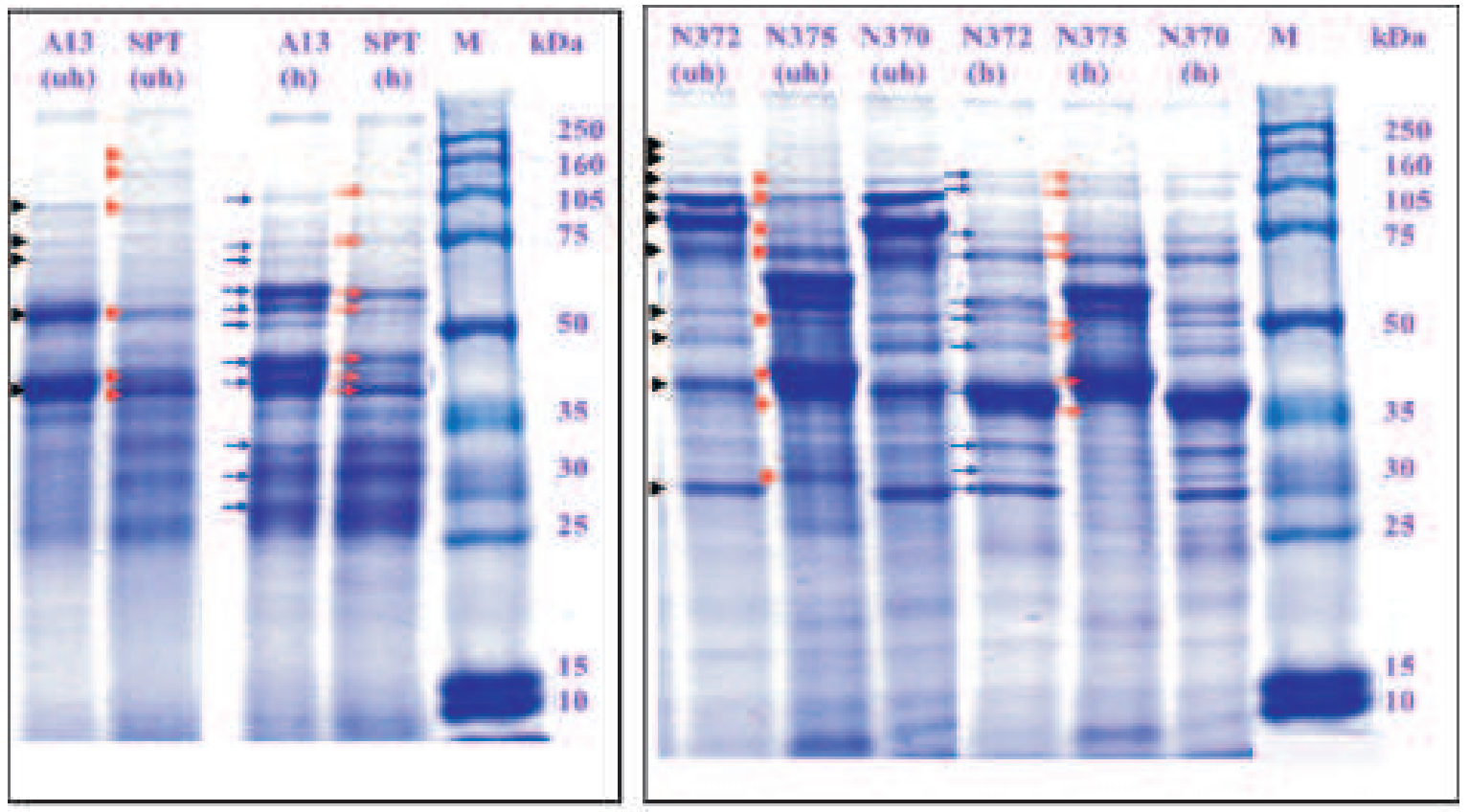

Gambar 2. Perbandingan profil protein Trypanosoma evansi antara isolat A13 dengan SPT dan antar isolat NTT pada gel poliakrilamid 12\% yang diwarnai dengan Coomassie Brilliant Blue.

(uh): tanpa pemanasan. (h): dengan pemanasan $65^{\circ} \mathrm{C}$ selama 5 menit

A13: isolat T. evansi dari Kabupaten Hulu Sungai Utara, Propinsi Kalimantan Selatan, SPT: isolat T. evansi dari Kabupaten Kotawaringin Timur, Propinsi Kalimantan Tengah, N370, N372 dan N375: isolat T. evansi dari Kabupaten Sumba Timur, Propinsi Nusa Tenggara Timur.

Arrowheads: pita protein awal sebelum mengalami pemanasan. Arrows: pita protein yang mengalami perubahan setelah pemanasan 
Tabel 2. Ringkasan perubahan profil pita protein dari T. evansi isolat N370, N372, A13 dan SPT berdasarkan hasil SDS PAGE pada gel poliakrilamid $12 \%$.

\begin{tabular}{cccccccccc}
\hline $\begin{array}{c}\text { Protein }) \\
(\mathrm{kD}\end{array}$ & $\begin{array}{c}\text { Isolat } \\
370^{\mathrm{a}}\end{array}$ & $\begin{array}{c}\text { Isolat } \\
370^{\mathrm{b}}\end{array}$ & $\begin{array}{c}\text { Isolat } \\
372^{\mathrm{a}}\end{array}$ & $\begin{array}{c}\text { Isolat } \\
372^{\mathrm{b}}\end{array}$ & $\begin{array}{c}\text { Protein } \\
(\mathrm{kD})\end{array}$ & $\begin{array}{c}\text { Isolat } \\
\mathrm{A13}^{\mathrm{a}}\end{array}$ & $\begin{array}{c}\text { Isolat } \\
\mathrm{A}^{\mathrm{b}}{ }^{\mathrm{b}}\end{array}$ & $\begin{array}{c}\text { Isolat } \\
\mathrm{SPT}^{\mathrm{a}}\end{array}$ & $\begin{array}{c}\text { Isolat } \\
\mathrm{SPT}^{\mathrm{b}}\end{array}$ \\
\hline 180 & + & - & + & - & 190 & - & - & \pm & - \\
140 & + & - & + & - & 140 & - & - & \pm & - \\
$100-120$ & + & + & + & + & $100-120$ & - & - & + & + \\
$95-100$ & ++ & + & ++ & + & 80 & - & - & - & \pm \\
$70-80$ & ++ & + & ++ & + & 60 & - & ++ & - & - \\
$\sim 60$ & + & + & + & + & 55 & - & + & - & + \\
$35=-60$ & 2 pita & 4 pita & 2 pita & 4 pita & 50 & ++ & + & + & + \\
35 & + & ++ & + & ++ & 40 & - & ++ & - & + \\
32 & - & + & - & + & 38 & +++ & ++ & + & + \\
$27-28$ & + & + & + & + & 35 & - & - & - & - \\
& & & & & 30 & - & + & - & - \\
& & & & & 28 & - & + & - & - \\
& & & & & $<25$ & - & + & - & - \\
\hline
\end{tabular}

Keterangan : Superscript: (a): tanpa pemanasan. (b): dengan pemanasan $65^{\circ} \mathrm{C}$ selama 5 menit. (+): pita protein yang ditemukan pada SDS PAGE. (-): pita protein yang tidak ditemukan pada SDS PAGE. $( \pm)$ : pita protein yang ditemukan pada SDS PAGE tetapi tampak samarsamar. $( \pm),(+),(++),(+++)$ : derajat ketebalan pita protein pada SDS PAGE. A13: isolat $T$. evansi dari kabupaten Hulu Sungai Utara propinsi Kalimantan selatan, SPT: isolat $T$. evansi dari Kabupaten Kotawaringin Timur, Propinsi Kalimantan Tengah, N370, N372 dan N375: isolat T. evansi dari Kabupaten Sumba Timur, Provinsi Nusa Tenggara Timur.

Di sisi lain, isolat N371 tidak menunjukkan perubahan migrasi dan ketebalan pita sehingga profil protein tetap tidak berubah. Hal ini menunjukkan bahwa protein yang divisualisasikan pada SDS PAGE dari isolat N371 lebih tahan terhadap pemanasan pada $65^{\circ} \mathrm{C}$ selama 5 menit. Pemanasan hingga mencapai $100^{\circ} \mathrm{C}$ selama 5 menit juga telah diketahui tidak menyebabkan perubahan profil protein dari isolat N371 pada SDS PAGE (data tidak dipublikasikan). Sebaliknya, isolat N375 hanya mengalami sedikit perubahan profil protein, terutama protein dengan bobot molekul $25 \mathrm{kDa}, 28 \mathrm{kDa}$ dan $50 \mathrm{kDa}$. Protein tersebut mengalami denaturasi sehingga hilang pada SDS PAGE setelah pemanasan pada $65^{\circ} \mathrm{C}$ selama 5 menit (Gambar 2 dan Tabel 2). Kemungkinan lain penyebab hilangnya ketiga pita protein tersebut karena degradasi oleh protease, namun hal ini dapat diabaikan karena adanya aprotinin sebagai antiprotease.

Secara keseluruhan, bukti-bukti tersebut menunjukkan bahwa keempat isolat $T$. evansi dari NTT (yaitu, N370, N372, N371, dan N375) tidak hanya memiliki profil protein yang berbeda tetapi juga berbeda sifat proteinnya, yaitu resistensi terhadap pemanasan. Oleh karena keempat isolat T. evansi asal NTT tersebut memiliki profil protein yang berbeda maka keempat isolat tersebut harus dipertimbangkan untuk ditempatkan dalam kelompok yang berbeda pula.

Perubahan bobot molekul dan kepadatan pita protein karena pemanasan pada $65^{\circ} \mathrm{C}$ selama 5 menit juga terjadi di TSA dari isolat A13 dan SPT. Pada isolat A13 terdapat dua pita protein yang tebal dengan bobot molekul sekitar $38 \mathrm{kDa}$ dan $50 \mathrm{kDa}$ (Gambar 2 dan Tabel 2). Setelah pemanasan, kedua pita protein tersebut mengalami perubahan ketebalan. Ini menunjukkan bahwa pita protein tersebut telah mengalami denaturasi yang menyebabkan perubahan ketebalan yang berkaitan dengan penurunan konsentrasi protein. Sebaliknya, pita protein dengan bobot molekul 25, 28, dan $30 \mathrm{kDa}$ serta 40, 55, dan $60 \mathrm{kDa}$ hanya ditemukan pada TSA dari isolat A13 yang dipanaskan sedangkan tanpa pemanasan tidak ditemukan. Protein yang mengalami denaturasi akan mengalami penurunan bobot molekul jika struktur primernya mengalami perubahan. Denaturasi protein juga dapat menyebabkan penipisan pita proteinnya akibat adanya sebagian protein yang rusak sehingga konsentrasinya berkurang. Pada 
penelitian ini menunjukkan adanya perbedaan profil dan sifat resistensi terhadap pemanasan protein antar isolat T. evansi. Hal tersebut dapat menunjukkan bahwa $T$. evansi yang ada di Indonesia mempunyai variasi walaupun isolat tersebut diisolasi pada waktu yang sama dan wilayah yang sama pula. Hal ini dapat menjadi informasi dasar mengenai profil protein isolat T. evansi dari Indonesia dalam pengembangan alat dan bahan diagnostik penyakit Surra di Indonesia.

\section{SIMPULAN}

Profil protein dari sebelas isolat T. evansi dari Indonesia menunjukkan adanya perbedaan yang berkaitan dengan pola dan kerapatan (ketebalan) pita proteinnya. Keragaman terjadi pada isolat yang berasal dari daerah yang sama dan diisolasi pada waktu yang sama. Perbedaan profil juga diikuti dengan perbedaan sifat ketahanan protein terhadap pemanasan. Secara keseluruhan hal ini mengindikasikan atau memberikan bukti awal adanya keragaman biologi terhadap populasi pada kesebelas isolat T. evansi dari beberapa daerah di Indonesia.

\section{SARAN}

Perlu adanya penelitian lebih lanjut mengenai protein spesifik dari isolat di Indonesia untuk pengembangan alat diagnosis yang spesifik dalam rangka mendukung upaya pengendalian Surra menurut keragaman/variasi T. evansi di Indonesia.

\section{UCAPAN TERIMA KASIH}

Penelitian yang didanai oleh APBN melalui Kerjasama dan Pemanfaatan Hasil Penelitian Balai Besar Penelitian Veteriner, Balai Veteriner Banjar Baru, dan Balai Veteriner Lampung.

\section{DAFTAR PUSTAKA}

Aquino LPCT, Machado RZ, Lemos KR, Marques LC, Garcia MV, Borges GP. 2010. Antigenic characterization of Trypanosoma evansi using sera from experimentally and naturally infected bovines, equines, dogs, and coatis. Revista Brasileira de Parasitologia Veterinária 19(2): 112-118.

Berber Ý, Berber. 2006. Numerical analysis of SDS-PAGE protein patterns of facultative alkaliphilic Bacillus species isolated from Lake Van, Turkey. FEB 15(5): 409-416.

Berber Ý, Ekin S. 2008. Discrimination and numerical analysis of human pathogenic Candida albicans strains based on SDS PAGE protein profiles. Afr J Biotechnol 7(4): 425-429.

Camargo R, Izquier A, Uzcanga GL, Perrone T, Acosta-Serrano A, Carrasquel L, Arias LP, Escalona JL, Cardozo V, Bubis J. 2015. Variant surface glycoproteins from Venezuelan trypanosome isolates are recognized by sera from animals infected with either Trypanosoma evansi or Trypanosoma vivax. Vet Parasitol 207: 17-33.

Delamare APL, Artico LO, Grazziotin FG, Echeverrigaray S, da Costa SOP. 2002. Total protein electrophoresis and RAPD fingerprinting analysis for identification of Aeromonas at the species level. Brazilian Journal of Microbiology 33: 358-362.

De-Menezes VT, Queiroz AO, Gomes MAM, Marques MAP, Jansen AM. 2004. Trypanosoma evansi in inbred and SwissWebster mice : distinct aspects of pathogenesis. Parasiol Res 94: 193-200.

DGLAH (Directorate General of Livestock and Animal Health). 2012. Guidelines forthe control and eradication Trypanosomiasis disease (Surra). Jakarta, Indonesia. Directorate of Animal Health, Directorate General of Livestock and Animal Health.

Ekawasti F, Yuniarto I, Subekti DT. 2015. Profil Protein Trypanosoma evansi Isolat S371 pada Elektroforesis dengan Reduksi dan Non-reduksi Ikatan Disulfida, Dalam: Prosiding Seminar Nasional Teknologi Peternakan dan Veteriner. Pro 15-93: 688694.

Giardina S, Paganico G, Urbani G, Rossi M. 2003. A biochemical and immunological comparative study on Trypanosoma equiperdum and Trypanosoma evansi. Vet Res Com 27: 289-300. 
Laha R, Sasmal NK. 2008. Characterization of immunogenic proteins of Trypanosoma evansi isolated from three different Indian hosts using hyperimmune sera and immune sera. Res Vet Sci 85: 534-539.

Laha R, Sasmal NK, Bandyopadhyay S. 2008. Comparative polypeptide profiles of whole cell lysate antigens of Trypanosoma evansi isolated from three different hosts of eastern India. J Protozool Res 18: 11-16.

Mejía AJ, Paláu MT, Zúñiga CA. 2004. Protein Profiles of Trypanosoma cruzi and Trypanosoma rangeli. Parasitol Latinoam 59: 142-147.

Navarro MC, De Lima AR, Askue J, Contreras VT. 2003. Morphological Comparison of Axenic Amastigogenesis of Trypomastigotes and Metacyclic Forms of Trypanosoma cruzi. Mem Inst Oswaldo Cruz 98(1): 1-9.

Nten CMA, Sommerer N, Rofidal V, Hirtz C, Rossignol M, Cuny G, Peltier JB, Geiger A. 2010. Excreted/Secreted Proteins from Trypanosome Procyclic Strains. J Biomed. Biotech. Vol. 2010, Article ID 212817, 8 pages doi:10.1155/2010/212817.

OIE (Office International des Epizooties). 2012. Trypanosoma evansi infection (Surra). OIE Terrestrial Manual 2012, Chapter 2.1.17. Hlm.1-15.

Pavel AB, Vasile CI. 2012. "PyElph - a software tool for gel images analysis and phylogenetics," BMC Bioinformatics 13: 9.

Queiroz AO, Legey AP, Xavier SCC, Jansen AM. 2001. Specific antibody levels and antigenic recognition of wistar rats inoculated with distinct isolates of Trypanosoma evansi. Mem Inst Oswaldo Cruz 96(7): 965-972.

Richards FF. 1984. The surface of African trypanosomes. J Protozool 32: 60-64.

Singh V, Singh A, Chhabra MB. 1995. Polypeptide profiles and antigenic characterization of cell membrane and flagellar preparations of different stocks of Trypanosoma evansi. Vet Parasitol 56: 269-279.
Sivajothi S, Rayulu VC, Reddy BS, Reddy BVS. 2015. Polypeptide Profiles of Whole Cell Lysate Antigens of Trypanosoma evansi Isolated From the Dogs by SDS-PAGE. $J$ Dairy Vet Anim Res 2(5): 00047. DOI: 10.15406/jdvar.2015.02.00047.

Smith TK, Vasileva N, Gluenz E, Terry S, Portman N, Kramer S, Carrington M, Michaeli S, Gull K, Rudenko G. 2009. Blocking variant surface glycoprotein synthesis in Trypanosoma brucei triggers a general arrest in translation initiation. PLoS ONE 4(10): e7532, 2009. doi:10.1371/ journal.pone.0007532.

Subekti DT, Sawitri DH, Wardhana AH, Suhardono. 2013. Pola Parasitemia dan Kematian Mencit yang diinfeksi Trypanosoma evansi Isolat Indonesia. Jurnal Ilmu Ternak dan Veteriner 18(4): 274-290.

Tahmourespour A, Nabinejad A, Shirian H, Ghasemipero N. 2013. The Comparison of Proteins Elaborated by Streptococcus mutans Strains Isolated from Caries Free and Susceptible Subjects. Iran J Basic Med Sci 16(4): 656-660.

Uche UE, Ross CA, Jones TW. 1992. Identification of the surface components of Trypanosoma evansi. Res Vet Sci 53: 252 253.

Velásquez NP, Camargo RE, Uzcanga GL, Bubis J. 2014. Partial purification of integral membrane antigenic proteins from Trypanosoma evansi that display immunological cross-reactivity with Trypanosoma vivax. J Parasitol Res Article ID 965815, 11 pages. doi:10.1155/2014/ 965815.

Yuniarto I. 2016. Karakterisasi protein isolat trypanosoma evansi dari wilayah kasus surra di Indonesia. Disertasi. Bogor. Institut Pertanian Bogor. 